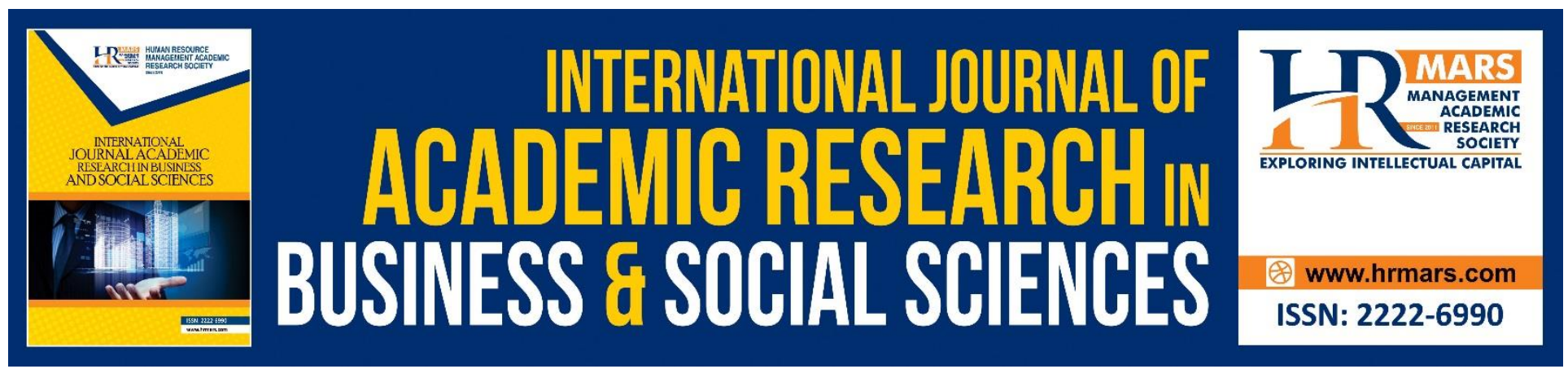

\title{
Crisis Management Models in the Holy Qur'an: The Story of Adam Peace Be Upon Him, as a Model
}

Abdulla Alqahtani

To Link this Article: http://dx.doi.org/10.6007/IJARBSS/v9-i5/5838

DOI: $10.6007 /$ IJARBSS/v9-i5/5838

Received: 25 March 2019, Revised: 14 April 2019, Accepted: 27 April 2019

Published Online: 19 May 2019

In-Text Citation: (Alqahtani, 2019)

To Cite this Article: Alqahtani, A. (2019). Crisis Management Models in the Holy Qur'an: The Story of Adam Peace Be Upon Him, as a Model. International Journal of Academic Research Business and Social Sciences, 9(5), 2238.

Copyright: (C) 2019 The Author(s)

Published by Human Resource Management Academic Research Society (www.hrmars.com)

This article is published under the Creative Commons Attribution (CC BY 4.0) license. Anyone may reproduce, distribute, translate and create derivative works of this article (for both commercial and non-commercial purposes), subject to full attribution to the original publication and authors. The full terms of this license may be seen

at: http://creativecommons.org/licences/by/4.0/legalcode

Vol. 9, No. 5, 2019, Pg. 22 - 38

http://hrmars.com/index.php/pages/detail/IJARBSS

JOURNAL HOMEPAGE

Full Terms \& Conditions of access and use can be found at http://hrmars.com/index.php/pages/detail/publication-ethics 


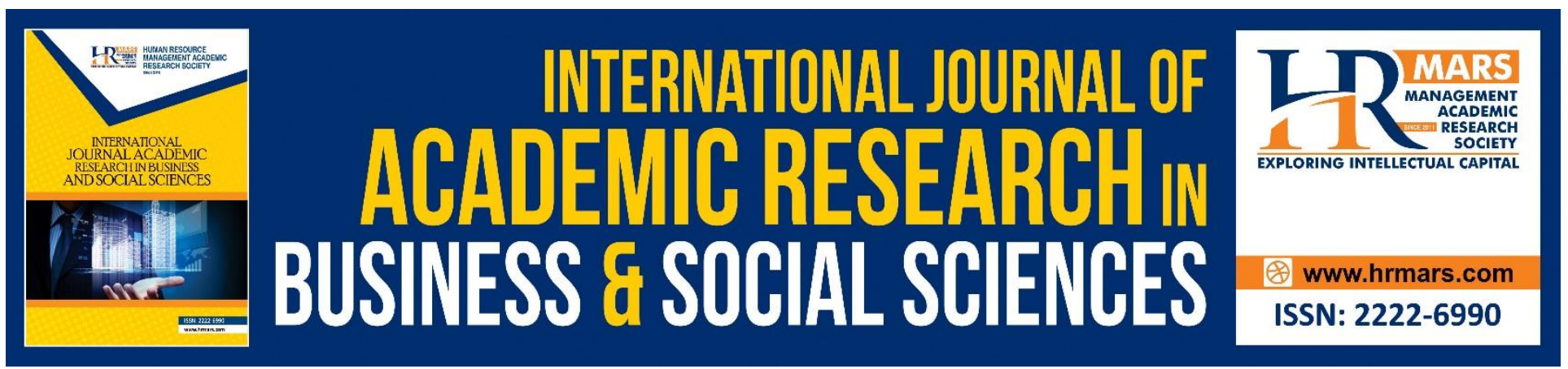

\title{
Crisis Management Models in the Holy Qur'an: The Story of Adam Peace Be Upon Him, as a Model
}

\author{
Abdulla Alqahtani \\ Centre for Islamic Development Management Studies (ISDEV), School of Social Sciences, 11800 \\ University Sains Malaysia, Pulau Penang, Malaysia
}

\begin{abstract}
This research tackles the crises in the Islamic world that threatens countries, communities and civil, governmental and private organisations. This study develops a model of crisis management from the Holy Qur'an to provide divine solutions to humanity to mitigate the spread of crises. To this end, this research examines and analyses the concept of crisis management models in the Holy Qur'an based on the story of Adam, peace be upon him. We determine how the Holy Qur'an defines and conceptualises crisis management in addition to its most prominent aspects as found in the story of Adam SAW. To answer these questions, this research refers to secondary data that were analysed using content analysis. The findings showed a mixture of physical and spiritual components in a manner that could not be separated while managing crisis in Islamic organisations.
\end{abstract}

Keywords: Crisis, Crisis Management, Crisis Management Models, Crisis Management Models in alQur'an, Crisis Models

\section{Introduction}

Muslims have ignored adhering to the teachings of the Qur'an which has resulted in the misery they are suffering today. The Almighty Allah has warned us in the Qur'an saying: "But he who turneth away from remembrance of $\mathrm{Me}$, his will be a narrow life, and I shall bring him blind to the assembly on the Day of Resurrection (124)" Surat Taha (Al-Yaziji, 2011). Qur'anic guidance is the only approach suitable for all people, everywhere and for all times. It has reformed individuals and communities through a fair and effective approach to remedy and avoid the crises suffered by humanity. The Almighty clarified the validity of the Qur'anic method by saying: "We shall show them Our portents on the horizons and within themselves until it will be manifest unto them that it is the Truth. Doth not thy Lord suffice, since He is Witness over all things? (53)" Fussilat (Boulagsaa, 2016).

This article is written to understand, examine and analyse the concept of crisis management in the Holy Qur'an based on the story of Adam SAW. The discussion is divided into five main sections. First, the concept of crisis management in the Holy Qur'an stories; second, definition of crisis in the Holy 
INTERNATIONAL JOURNAL OF ACADEMIC RESEARCH IN BUSINESS AND SOCIAL SCIENCES Vol. 9, No. 5, May, 2019, E-ISSN: 2222-6990 ㄷ 2019 HRMARS

al-Qur'an; third, the research methodology; fourth, analysing the crisis management model in alQur'an: Adam SAW story as a model; and fifth, the results.

The Concept of Crisis Management in the Stories of the Holy Qur'an

The Almighty has narrated in the Holy Qur'an the stories of former nations and key personalities, and described these stories as being the best stories. The Almighty said: "We narrate unto thee (Muhammad) the best of narratives in that We have inspired in thee this Qur'an, though aforetime thou wast of the heedless. (3)" Surat Yusuf. The Holy Qur'an contains many stories as lessons for those who reflect and contemplate their meanings and lessons. He said: "In their history verily there is a lesson for men of understanding (111)" Surat Yusuf; and clarified to us that the stories of the Holy Qur'an are true: "We narrate unto thee their story with truth. (13)" Surat Al Kahf (Badran, 2011).

Al Muzayen (2009) added that the educational methods vary in the stories of the Holy Qur' an perhaps to address the different ways in which people learn. He considered the method of narration used in the Holy Qur'an as a method that conveys experiences indirectly to the learner, which makes the learner more convinced and satisfied. He added that the repetition in the Qur'anic narrative emphasises to the learner the expected outcome or results of the lesson so one can correct their behaviour accordingly. This method teaches the learner the need for hearing and seeing repeatedly until the meanings settle in the minds. This is made clear in the verse: "Will they then not meditate on the Qur'an, or are there locks on the hearts? (24)" Surat Mohammed.

Al-Kailani (2009) affirmed that the stories of the Qur'an contain many concepts, including crisis management, but the focus of scholars is on the use of these concepts in the aspects of ethics, selfdiscipline and others. The objective of this research is to explore the Islamic values and jurisprudential content in the Qur'anic stories to develop a clear understanding of administrative concepts to improve the ways in which we face and manage crises. Al-Kailani (2003) added that the ability of applying the art of crisis management is a prudent condition imposed by jurists in dealing with crises and considered the ability to manage crises necessary for the survival of organisations in facing sedition, which is the real test of management efficiency.

Al-Otaibi and Al-Khlaiwi (2018) agree with Al-Kailani (2003) that many Muslim scholars have studied the stories of the Qur'an and extracted lessons and examples. This study refers to such studies to confirm that the origin of the science of crisis management is found in the Qur'an, despite being considered a modern trend in contemporary administrative thought. Doing so indicates the distinction of Islamic management on contemporary management. It also supports that Muslims should have a distinct approach to managing crises effectively that advocate Islamic lessons. The Islamic approach to crisis management is an accumulated intellectual approach and offers potent solutions to the crises plaquing the Muslim world, as it is inspired by the Holy Qur'an and Sunnah (AlOtaibi and Al-Khlaiwi, 2018).

Crises occur individually, collectively, and at the organisational level, and are as old as human beings. A crisis has the potential to benefit man if it learns from it. Fundamentally, it is a test. Whosoever overcomes the test and perseveres should learn from it and avoid its recurrence by avoiding its causes. However, those who fail to learn from the crisis are doomed to repeat it and it becomes harder to overcome (Abdullah and Hedayat, 2013). 


\section{The Meaning of Crisis in the Holy Qur'an}

Crisis is one of the most widespread concepts in contemporary society as it affects all aspects of life directly or indirectly. Crises are dynamic and consists of stages, characteristics and causes. It affects all societies and organisations. Overcoming them is vital, and as such this research shall explain the concept of crisis in the Qur'an according to the former studies (Yaziji, 2011).

Boulagsaa (2016), Al-Otaibi, Al-Khlaiwi (2018) and Al-Kailani (2003) confirmed that the term crisis is not mentioned in the Holy Qur'an, even in a derivative manner. Nevertheless, several synonyms indicate the conventional meaning of crisis. We find that the Holy Qur'an refers to crises in different terms and places, which all indicate the conventional meaning of crisis.

The Holy Qur'an has referred the term "sedition" to crisis. Sedition shares several characteristics with the crisis such as destroying organisations and threatening values, as in the verse: "And guard yourselves against a chastisement which cannot fall exclusively on those of you who are wrongdoers, and know that Allah is severe in punishment. (25)" Surat Al Anfal. We draw from this verse some of the characteristics of a crisis as affecting everyone and threatening the security of the society and organisation. This is in line with the modern administrative view that considers a crisis as a critical situation threatening the security and stability of organisations (Al-Otaibi and Al-Khlaiwi, 2018).

Boulagsaa (2016) added that the term "affliction" reflects crisis. Whatever advocates evil is part of affliction. However, not every affliction is a crisis as the Almighty said: "and We try you with evil and with good, for ordeal. And unto Us ye will be returned. (35)" Surat Al-Anbiyaa. Affliction is in the sense of testing and examining, and what afflicts human beings involves good and evil alike.

Al-Kailani (2003) believes that the crisis was also mentioned in the Holy Qur'an by the term "calamity". Allah Almighty says: "And was it so, when a disaster smote you, though ye had smitten (them with a disaster) twice (as great), that ye said: How is this? Say (unto them, O Muhammad): It is from yourselves. Lo! Allah is Able to do all things. (165)" Surat Al-Imran. Defeat in battle is a crisis, and its effects need to be managed. The first step in its correction is the recognition of error and not blaming others. This is what the verse addresses.

The Holy Qur'an uses the term "misfortune" as a synonym to crisis in the verse: "but give glad tidings to the steadfast (155), who say, when a misfortune striketh them: Lo! we are Allah's and lo! unto Him we are returning. (56)" Surat Al Baqara. It is an important guide for confronting a crisis when it happens to be able to overcome it, contain the damage, control its impact and restore normal activity. In this research, we shall present some of the models of crisis management in the Qur'an and discuss it using deductive analysis of the Qur'anic approach to crises management (Al-Otaibi and Al-Khlaiwi, 2018).

Crisis also reveals what is in the hearts to distinguish the believer from the hypocrite, the sincere from the liar; as the term "scrutiny" means the trial of believers to purify and cleanse them from sins, as stated in the verse: "And that Allah may prove those who believe, and may blight the disbelievers.(141)" Surat Al-Imran. Crises are necessary to harden and strengthen the believers' faith, and Allah Almighty has mentioned part of the scrutiny of believers in the battle of Uhud in Surat Al-Imran: "in order that Allah might try what is in your breasts and prove what is in your hearts. Allah is Aware of what is hidden in the breasts (of men). (154)". (Boulagsaa, 2016).

As for the term "distress", it comes in the sense of testing to purify and rid the hearts of the believers from impurities, as Allah Almighty has afflicted them with crises and tribulations that test and 
strengthen their faith. The Almighty says: "O ye who believe! When believing women come unto you as fugitives, examine them. Allah is Best Aware of their faith. (10)" Surat Al Mumtahana. As for the term "agony", it refers to sadness, distress and crisis that result from hardship as in the verse: "And We saved him and his household from the great distress, (76)" Surat Al Safat (Al Shaikh, 2003).

Crisis is also expressed in the term "severity" which refers to the intensity of life. The Holy Qur'an refers to this meaning in the verse: "Then after that will come seven hard years... (48)" Surat Yusuf. The term "hardship" is in contrast to ease, as hardship means suffering, adversity and difficulty. The norm of the Almighty is such that a crisis will one day come to an end, and those who persevered shall be enriched and experience ease. The Almighty says: "Allah will vouchsafe, after hardship, ease. (7)" Al Talaq and the verse: "Lo! with hardship goeth ease; (5)" Surat Al Sharh. The term "detriment" expresses crisis in terms of severity, harm and a bad situation. This is illustrated in the verse: " $O$ ruler! Misfortune hath touched us and our folk, and we bring but poor merchandise... (88)" Surat Yusuf (Usama, 2002).

Boulagsaa (2016) states that these terms are considered synonyms of crisis in the Holy Qur'an and Qur'an is rich with their use. Other synonyms for crisis in the Qur'an is the term "evil", as in the verse: "Is not He (best) Who answereth the wronged one when he crieth unto Him and removeth the evil... (62)" Surat Al Naml. The term "earthquake" is also used to signify repeated disorder as in the verse: "Or think ye that ye will enter Paradise while yet there hath not come unto you the like of (that which came to) those who passed away before you? Affliction and adversity befell them, they were shaken as with earthquake, till the messenger (of Allah) and those who believed along with him said: When cometh Allah's help? Now surely Allah's help is nigh. (214)" Surat Al Baqara; as well as the verse: "There were the believers sorely tried, and shaken with a mighty shock. (11)" Surat Al Ahzab.

The term "years" is used to refer to drought in the Holy Qur'an as in the verse: "And we straitened Pharaoh's folk with famine and dearth of fruits that peradventure they might heed. (130)" Surat Al A'araf. Concerning this type of crisis, the Holy Qur'an uses synonyms such as "thirst, fatigue and hunger" in the verse: "It is not for the townsfolk of Al-Madinah and for those around them of the wandering Arabs so stay behind the messenger of Allah and prefer their lives to his life. That is because neither thirst nor toil nor hunger afflicteth them in the way of Allah, nor step they any step that angereth the disbelievers, nor gain they from the enemy a gain, but a good deed is recorded for them therefor. Lo! Allah loseth not the wages of the good. (120)" Surat Al Tauba (Boulagsaa, 2016).

\section{Research Methodology}

This qualitative study used secondary data. Content analysis was performed to analyses the data collected from the secondary sources which comprised related literature such as thesis, journals and writings related to the concept of crisis management from an Islamic perspective. Next, the models of crisis management are explored by referring to the main sources of Islam, which is al-Qur'an and the literature related to the scriptures of interpretation and published studies. 
INTERNATIONAL JOURNAL OF ACADEMIC RESEARCH IN BUSINESS AND SOCIAL SCIENCES Vol. 9, No. 5, May, 2019, E-ISSN: 2222-6990 ㄷ 2019 HRMARS

Analysis of Crisis Management Model in the Holy Qur'an: The Story of Adam, Peace Be Upon Him The Holy Qur'an is rich in models, and generally the model is considered a situation based on a set of preludes, conditions and circumstances that generate a special and distinctive model. Models are considered test fields ready for solutions from history. We could make the models of the Holy Qur'an as a standard for setting solutions and treatments for crises, especially if they share similar circumstances or reasons, because it produces standard models in which the elements overlap. We could refer to such models for developing solutions to crises. Such models shall become references based on the Sharia, which we believe in, because it is derived from the Holy Qur'an (Shaikh, 2003). Osama (2002) said that those who read the Holy Qur'an and review the noble Sunnah, shall find many ideas and administrative concepts applied in our time. Although the functions of management in their modern names are not mentioned in the Holy Qur'an, their substance and processes are. Al-Yaziji (2011) confirmed that crisis management has been found in practice since ancient times and was a manifestation of human beings dealing with emergency or critical situations. At that time, it was not known as crisis management, but under other names such as wisdom, skilled leadership or good management, and others. The Holy Qur'an has established the scientific and practical foundations of the science of crisis management, particularly through its use of stories. These examples and stories are the true test of the human ability to confront crises and deal with critical situations in creative and innovative ways.

Al-Kailani (2003) added that a crisis is a crucial challenge facing the administration by putting the institution at a crossroads as it poses a serious threat to existence and entities. Despite the dangers of a crisis, it carries within it a number of positives by providing an opportunity for change, prepares the atmosphere for the emergence of leaders, stimulates early warning systems, enables facing the problems and gives the management a new competitive ability. Such benefits are possible when a crisis is analysed and its reasons studied from which we can develop the strategic and systematic solutions.

This research focuses on one of the most prominent types of crises experienced by the Muslim community through the study of Qur'anic analysis in the light of the former theoretical studies. In this research, we shall address the crisis of Adam (PBUH) and his wife. Their disobedience of the orders of Almighty led to their eviction from Paradise to Earth.

This section shall be divided into three sections. First: type of crisis, definition and explanation, second: the reasons led to crisis, third: analysis of the crisis. The analysis will be divided into five stages, through which most crises shall pass. First: the detection of early warning signals, which is a warning stage, second: the readiness and prevention, which is the stage of the emergence of crisis, third: the containment and reduction of damages, which is the stage of occurrence of crisis, fourth: the restoration of activity, which is the stage of the decline of crisis, fifth: the continuous learning of improvement, which is a summary of the lessons learned from the crisis (Yaziji, 2011; Al-Otaibi and Al-Khlaiwi, 2018; Kailani, 2003).

\section{Type of Crisis}

Al-Yaziji (2011) regards the crisis of Adam (PBUH) is a general crisis concerning all aspects of being, society, organisation, and nation. He added that it affects all parties and persons, products and internal and external components of a system. Osama (2002) called it the 'comprehensive crisis'. 
Nabil and Adnan (2013) defined it as a total crisis as it is not confined to a single sector or aspect but extends to the whole system.

Shaqra (1995) defined it as a crisis at the overall level, affecting all entities, whether a country, a society or an institution, and described it as being comprehensive in all its causes, consequences and remedies. Khalidi (2017) agreed with Shaqra (1995) that the overall crisis occurs at the entity level as a whole and all elements in the entity are affected by it. He considered it as comprehensive and general crises in their causes and results. Khalil (2016) regards it as a crisis that conflicts with the law of Allah and Sunnah, and conflict with values and ethics. He defined it as inhuman acts contrary to the principles and existence of human being and their creation.

\section{Reason of Crisis}

The crisis has introductions and an incubating atmosphere considered as the causes and conditions of the crisis. Whoever perpetrates its causes will experience its results, and whoever avoids its causes, avoids the test. We need to reflect on the mentality of the person pondering the Holy Qur'an to understand the causes of the crisis of Adam (PBUH) and the preceding indicators. The causes of the crisis and overcoming it are considered divine rules relevant to Muslim and non-Muslim. Such reasons are needed for Muslim administrator or Islamic organisations due to the seriousness of the consequences if elapsed. The reasons that led to the crisis of Adam (PBUH) were the admiration and arrogance of Satan, which led Adam (PBUH) to underestimate the consequences of his actions (Shaikh, 2003).

Osama (2002) states that the first general or comprehensive crisis the occurred in the history of creation, according to the Holy Qur'an and in the Islamic perspective, is the crisis of the devil when it rejected the command of Allah Almighty by refraining to prostrate to Adam (PBUH). The verse states: "And when We said unto the angels: Prostrate yourselves before Adam, they fell prostrate, all save Iblis. He demurred through pride, and so became a disbeliever. (34)" Surat Al Baqara. This verse shows that disobeying the Almighty is a crisis, and some scholars described it as crisis borne of pride. Therefore, Satan was expelled from the mercy of Allah forever. The Almighty states: "He said: $\mathbf{O}$ Iblis! What hindereth thee from falling prostrate before that which I have created with both My hands? Art thou too proud or art thou of the high exalted? (75), he said: I am better than him. Thou createdst me of fire, whilst him Thou didst create of clay. (76), He said: Go forth from hence, for lo! thou art outcast, (76), and lo! My curse is on thee till the Day of Judgement. (77)" Surat Sad (AlTabari, 2001).

\section{Analysis of Crisis}

In the same context, the Almighty said to Adam (PBUH) and his wife in Surat Al-A'raf: "Lo! Satan is an open enemy to you? (22)", and in Surat Taha the Almighty says: "Therefore we said: O Adam! This is an enemy unto thee and unto thy wife, so let him not drive you both out of the Garden so that thou come to toil. (117)". As a result of this hostility, this was the second crisis for the creation and the first for Adam (PBUH). It is considered the first crisis in the history of mankind when Satan misled and whispered to them. The Almighty says: "Then Satan whispered to them... (20)" Surat Al A'araf. Satan plunged Adam (PBUH) and his wife into crisis as the Almighty says: "Thus did he lead them on with guile... (22)" Surat Al A'araf (Ibn Katheer, 2000). 
Since that time, according to the verses mentioned above, Satan and his soldiers will continue to be enemies to the sons of Adam. The Almighty says in Surat Sad: "He said: Then, by Thy might, I surely will beguile them every one, (82)". In Surat Al Isra, the Almighty says: "He said: Seest Thou this (creature) whom Thou hast honoured above me, if Thou give me grace until the Day of Resurrection I verily will seize his seed, save but a few. (62)". Some people are excluded people as the Almighty says: "Save Thy single-minded slaves among them. (83)" Surat Sad. As well, in Surat Al Isra, the Almighty says: "Lo! My (faithful) bondmen - over them thou hast no power, and thy Lord sufficeth as (their) guardian. (65)". This refer to the worshipers of Allah who obey Him, follow His commands and oppress the devil (Tabari, 2001).

\section{Reading the Warning Signals}

Al-Hamlawi (1995) defined it as a precautionary stage and indicated that a crisis sends a series of early warning signs and symptoms that predicate the possibility of a crisis occurring. Al-Kailani (2003) agreed with Al-Hamlawi (1995) that there are pre-crisis precautionary warning signs. He added that it is a divine warning by which the Almighty threatens His slaves so that they may review their behaviour and avoid crisis. He also pointed out that if a person can read the early signals, he/she would then have the opportunity to correct the defect.

Osama (2002) reported that the Almighty ordered Adam and his wife to stay in Paradise and eat from it whatever they wanted and warned them from approaching one of the trees. He says: "And when We gave unto Moses the Scripture and the criterion (of right and wrong), that ye might be led aright. (35)" Surat Al Baqara. The Almighty also warned Adam (PBUH) that the Satan is an enemy to him and his wife's enemy and warned him of being expelled from Paradise due to obedience. The Almighty says in Surat Taha: "Therefore we said: O Adam! This is an enemy unto thee and unto thy wife, so let him not drive you both out of the Garden so that thou come to toil. (117)" (Ibn Katheer, 2000).

The Almighty continued in Surat Taha: "It is (vouchsafed) unto thee that thou hungerest not therein nor art naked (118), And that thou thirstest not therein nor art exposed to the sun's heat.(119)". This means that you, Adam, shall not starve in Paradise, nor will you be naked, nor will you be thirst, nor will you feel the heat of the sun. It indicates that Adam will be clothed and have food, drink, and dwellings. All this is a warning to Adam (PBUH) that "if you miss the commandment and disobey the Almighty and follow and obey the Satan - your enemy - then you will be expelled from Paradise and will starve, become exhausted and wretched, then you will be hungry, thirsty and will feel the heat of the sun (Al-Qurtubi, 2006).

\section{Preparation and Prevention}

Al-Otaibi and al-Khlaiwi (2018) considered this the stage of the emergence of crisis. At this stage, the sense of crisis grows and cannot be ignored. Al-Yaziji (2011) added that it is difficult to prevent something that is not foreseen or foreshadowed. Al-Kailani (2003) considered it the stage of planning to prevent the crisis by developing programs to confront and prevent it. Plans or programs are often adopted on the basis of the previous stage, which is the warning stage, to train the staff in the institution to cope with crises. 
INTERNATIONAL JOURNAL OF ACADEMIC RESEARCH IN BUSINESS AND SOCIAL SCIENCES

Vol. 9, No. 5, May, 2019, E-ISSN: 2222-6990 @ 2019 HRMARS

Despite the warning of the Almighty to Adam and his wife in the first stage, they forget His commands: "And verily We made a covenant of old with Adam, but he forgot, and We found no constancy in him. (115)" Surat Taha. Satan whispered to them which represents the stage of the emergence of crisis. The verse says: "Then Satan whispered to them... (20)" Surat Al A'araf. And in Surat Al Baqara, the Almighty says: "But Satan caused them to deflect therefrom... (36)".

Osama (2002) states that the term 'slip' is derived from slippage, which is the stumbling or tripping of the foot, which means that Adam and his wife ate from the tree. The phrase "slipped them" means the Satan called them to slip. Al-Qurtubi said (2006) that Satan drew them to sin and continued cheating them and led them covertly. The verse says: "Thus did he lead them on with guile ...(22)" Surat Al A'araf. (Al-Tabari, 2001).

Satan continued whispering to Adam and his wife and tempted them to eat from the thee that the Almighty had forbidden and warned them not to approach. He says: "But the devil whispered to him, saying: O Adam! Shall I show thee the tree of immortality and power that wasteth not away? (120)" Surat Taha. Satan said to Adam and his wife "your Lord has prevented you from this tree only lest you become two angels", as the verse states in Surat Al A'araf says: "and he said: Your Lord forbade you from this tree only lest ye should become angels or become of the immortals. (20)". Satan was not content with that, but swore to Adam and his wife that he was advising them. The verse says: "And he swore unto them (saying): Lo! I am a sincere adviser unto you. (21)". Surat Al A'araf. (AlQurtubi, 2006).

\section{Containing the Damage}

Al-Kailani clarified (2003) that this is the stage of controlling the effects of the crisis by decreasing the severity of crisis. Al-Yaziji (2011) and Al-Otaibi and Al-Khlaiwi (2018) considered it the stage of crisis outbreak. It requires a person to have the means to reduce the damage and prevent it from spreading. Al-Hamlawi (1995) added that it is a stage in which the crisis management must consider the nature of the incident.

In the containment of a crisis, Shaikh (2003) said, although the Almighty addressed Adam (PBUH) with several orders and prohibited him and his wife from eating from the tree, Adam forgot due to the whispers of Satan that tempted him to eat from the tree. The Almighty says: "Then they twain ate thereof, so that their shame became apparent unto them, and they began to hide by heaping on themselves some of the leaves of the Garden. And Adam disobeyed his Lord, so went astray. (121)" Surat Taha. Al-Tabari (2001), added their private parts, which were previously concealed, were exposed to them and they set out covering themselves with the leaves of Janah. This was because they disobeyed the command of Allah Almighty and ate from the forbidden tree.

Osama (2002) added that the result of the disobedience of Adam (PBUH) and his wife of the Almighty by listening to the Satan and eating from the tree resulted in exposing their private parts. The Almighty says: "And when they tasted of the tree their shame was manifest to them and they began to hide (by heaping) on themselves some of the leaves of the Garden... (22)". Surat Al A'araf. Hence the crisis occurred after Adam and Eve disobeyed the commands of the Almighty and ate from the tree. This was the first crisis in the history of humanity caused by Satan. Ibn Katheer (2000) also stated that as a result of the sin of Adam and his wife, their private parts were revealed. He says: "...that he might manifest unto them that which was hidden from them of their shame..., (20)". Surat Al A'araf. 
INTERNATIONAL JOURNAL OF ACADEMIC RESEARCH IN BUSINESS AND SOCIAL SCIENCES

Vol. 9, No. 5, May, 2019, E-ISSN: 2222-6990 ㄷ 2019 HRMARS

\section{Restoration of Activity}

Al-Otaibi and Al-Khleiwi (2018) and Al-Yaziji (2011) considered this to be a stage of a crisis that comes after assessing the losses, adapting with the situation and restoring things to normal conditions through efforts to eliminate the crisis and reduce its impact. Al-Kailani (2011) considered it as the operations or procedures carried out by the executive organs in the organisations to restore balance in the exercising of its work and repair the impact of damage.

The restoration of activity reflects a decline in the crisis. Shaikh said (2003), the reason for this stage is that Adam forgot and Satan whispered to him to eat from the tree. The result was the wrath of the Almighty and ordering him and his wife to descend to the Earth. The Almighty says: "and We said: Fall down, one of you a foe unto the other! There shall be for you on Earth a habitation and provision for a time. ..., (36)". Surat Al Baqara. The Almighty repeated this in Surat Al A'araf saying: "He said: Go down (from hence), one of you a foe unto the other. There will be for you on Earth a habitation and provision for a while. (24)". Al-Tabari (2001) confirmed that the descent was from Heaven to Earth. Ibn Katheer (2000) added that the verse was addressing Adam, Eve, and Satan.

Osama (2002) said that the Almighty had mercy on Adam (PBUH) despite his disobedience and brought him down to the Earth. This is mentioned in the verse: "He said: Go down hence, both of you, (123)". Surat Taha. Ibn Katheer (2000) added "and then that the treatment of Adam, peace be upon him and his wife recognised their sin and repented to the Almighty". The verse says: "They said: Our Lord! We have wronged ourselves. If thou forgive us not and have not mercy on us, surely we are of the lost! (23)". Surat Al A'araf. Then Allah chose Adam after disobeying Him and bestowed upon him the returning to what pleases Allah and guided him to repentance. The Almighty says: "Then his Lord chose him, and relented toward him, and guided him. (122)". Surat Taha. Adam repented to the Almighty who accepted his repentance. The verse says: "Then Adam received from his Lord words (of revelation), and He relented toward him. Lo! He is the relenting, the Merciful. ..., (37)". Surat Al Baqara (Al-Tabari, 2001).

\section{Learning Lessons}

Al-Otaibi and Al-Khleiwi (2018) defined this as a stage of compensation in which the process of evaluation and avoidance of effects occur. Al Yaizji (2011) added that it is the final stage of crisis management, which is the stage of continuous learning and re-evaluation to improve what had been achieved in the past. Learning the lesson is vital, but it is very painful and evokes painful memories left by the crisis. Shaikh (2003) considered learning the lesson as a change in tendency to respond under the influence of experience, and learning must be supported by continuity, accompanied by practice and experience to allow the individual to retain what he has learned.

Al-Kailani (2011) considered it an evaluation and study stage for the cause of crisis to know the shortcomings and manage to overcome it and face the future with greater competitiveness and with the intention of not repeating the error. He added that the Holy Qur'an has confirmed the principle of reviewing mistakes. The verse states: "Then Adam received from his Lord words (of revelation), and He relented toward him. Lo! He is the relenting, the Merciful. ..., (37)". Surat Al Baqara. AlKailani considered that mentioning the error in the story was for consideration and review and this is what Adam's offspring needs. Allah says: "...Will ye choose him and his seed for your protecting 
friends instead of Me, when they are an enemy unto you? Calamitous is the exchange for evil-doers. (50)". Surat Al Kahf.

Thus was the first crisis of all humankind, and it was the mercy of the Almighty accepting the repentance of Adam (PBUH) despite his disobedience. Of all this, the sons of Adam must follow the lesson and be cautious, and try repentance and good deeds, and obey the Almighty to obtain Paradise on the Day of Resurrection. The task of the Muslim does not end with the end of the crisis; its role continues by maintaining one's integrity to avoid a more severe crisis in the future. In confirmation of this, the Almighty said in Surat Yunus: "And if misfortune touches a man he crieth unto Us, (while reclining) on his side, or sitting or standing, but when We have relieved him of the misfortune he goeth his way as though he had not cried unto Us because of a misfortune that afflicted him. Thus is what they do made (seeming) fair unto the prodigal. (12)". (Shaqra, 1995, Al-Tabari, 2001). This is illustrated in Table 1:

\begin{tabular}{|c|c|c|}
\hline No. & Learning and lessons summarising & Verses of the Holy Qur'an \\
\hline 1 & $\begin{array}{l}\text { - Most of the crises arise as a result } \\
\text { of disobeying the Almighty and } \\
\text { being away from His approach } \\
\text { (Osama, 2002, Shaikh, 2003) }\end{array}$ & $\begin{array}{l}\text {...But when there come unto you from Me a } \\
\text { guidance, then whoso followeth My guidance, he } \\
\text { will not go astray nor come to grief.(123). But he } \\
\text { who turneth away from remembrance of Me, his } \\
\text { will be a narrow life,... (124)." Surat Taha. } \\
\text { - ...from hence; but verily there cometh unto you } \\
\text { from Me a guidance; and whoso followeth My } \\
\text { guidance, there shall no fear come upon them } \\
\text { neither shall they grieve. (38) But they who } \\
\text { disbelieve, and deny Our revelations, such are } \\
\text { rightful Peoples of the Fire. They will abide therein. } \\
\text { (39)." Surat Al Baqara. }\end{array}$ \\
\hline 2 & $\begin{array}{l}\text { - Satan is the greatest enemy of } \\
\text { man and his hatred of the sons of } \\
\text { Adam will not cease. This is one of } \\
\text { the causes of crises (Kailani, 2003) }\end{array}$ & $\begin{array}{l}\text { - O Children of Adam! Let not Satan seduce you as } \\
\text { he caused your (first) parents to go forth from the } \\
\text { Garden and tore off from them their robe (of } \\
\text { innocence) that he might manifest their shame to } \\
\text { them. Lo! he seeth you, he and his tribe, from } \\
\text { whence ye see him not. Lo! We have made the } \\
\text { devils protecting friends for those who believe not. } \\
\text { (27)." Surat Al A'raf. } \\
\text { - He said: Go, and whosoever of them followeth } \\
\text { thee - lo! Hell will be your payment, ample } \\
\text { payment. (63) And excite any of them whom thou } \\
\text { canst with thy voice, and urge thy horse and foot } \\
\text { against them, and be a partner in their wealth and } \\
\text { children, and promise them. Satan promiseth them } \\
\text { only to deceive. (64)." Surat Al Israa. }\end{array}$ \\
\hline
\end{tabular}


INTERNATIONAL JOURNAL OF ACADEMIC RESEARCH IN BUSINESS AND SOCIAL SCIENCES Vol. 9, No. 5, May, 2019, E-ISSN: 2222-6990 @ 2019 HRMARS

\begin{tabular}{|c|c|c|}
\hline 3 & $\begin{array}{l}\text { - Persons who are driven by the evil } \\
\text { self who have obeyed and } \\
\text { committed to its desires and calls of } \\
\text { Satan, are more likely to experience } \\
\text { crises (Osama, 2002) }\end{array}$ & $\begin{array}{l}\text { - I do not exculpate myself. Lo! the (human) soul } \\
\text { enjoineth unto evil, save that whereon my Lord } \\
\text { hath mercy. Lo! my Lord is Forgiving, Merciful. } \\
\text { (53)." Surat Yusuf. }\end{array}$ \\
\hline 4 & $\begin{array}{l}\text { - Afflictions and sedition are tests } \\
\text { that lead to the emergence of crises } \\
\text { (Shaqra, 1995) }\end{array}$ & $\begin{array}{l}\text {-... And We try you with evil and with good, for } \\
\text { ordeal. And unto Us ye will be returned. (35)." } \\
\text { Surat Al-Anbiyaa } \\
\text { - .... And surely We shall try you with something of } \\
\text { fear and hunger, and loss of wealth and lives and } \\
\text { crops; but give glad tidings to the steadfast. } \\
\text { (155)." Surat Al Baqara. } \\
\text { - Assuredly ye will be tried in your property and in } \\
\text { your persons, and ye will hear much wrong from } \\
\text { those who were given the Scripture before you, } \\
\text { and from the idolaters. But if ye persevere and } \\
\text { ward off (evil), then that is of the steadfast heart } \\
\text { of things. (186)." Surat Al-Imran. }\end{array}$ \\
\hline 5 & $\begin{array}{l}\text { - Sanctions sent by the Almighty on } \\
\text { the infidels, disobedience and the } \\
\text { disbelievers cause crises because of } \\
\text { their sins (Shaikh, 2003) }\end{array}$ & $\begin{array}{l}\text { - So We took each one in his sin; of them was he on } \\
\text { whom We sent a hurricane, and of them was he } \\
\text { who was overtaken by the (Awful) Cry, and of them } \\
\text { was he whom We caused the Earth to swallow, } \\
\text { and of them was he whom We drowned. It was not } \\
\text { for Allah to wrong them, but they wronged } \\
\text { themselves. (40)." Surat Al Ankabut. } \\
\text { - Allah coineth a similitude: a township that dwelt } \\
\text { secure and well content, its provision coming to it } \\
\text { in abundance from every side, but it disbelieved in } \\
\text { Allah's favours, so Allah made it experience the } \\
\text { garb of dearth and fear because of what they used } \\
\text { to do. (112)." Surat Al Nahl. }\end{array}$ \\
\hline
\end{tabular}

Table 1: Learning Items and Summary of Lessons

Based on Table 1, the researcher wrote the learning items and summarised the lessons learned from the crisis experienced by Adam (PBUH). The table contains five items related to learning outcomes, summarising the lessons from the aforementioned crisis in accordance with the Qur'anic references.

Results

Crises are a natural humanitarian condition by which both groups and individuals are afflicted, the reactions vary from one group to another. The group of believers is distinguished from other human groups. They are distinguished by the way they face the crises and afflictions. It is an educational 
experience for the believing community that should foster a closer relationship with God. The Holy Qur'an described the tribulations and crises and clarified the causes of tribulations and crises to help the believing group cope with it. The Holy Qur'an has revealed the means and methods of treatment and confrontation of these crises, as the Almighty has not left this nation without divine support and education (Yaziji, 2011).

\section{The Qur'anic approach in the story of Adam (PBUH) for managing the crises}

Al-Otaibi and Al-Khlaiwi (2018) reported that the Qur'anic approach to crisis management is a balanced approach, combining theory and practice with the interest of the individual and community. It is a unique approach with its intellectual principles, value bases, humanitarian aspects and its interest in material and moral aspects during crisis.

This research concludes that it is not enough for the Muslim world to fulfil the physical components which is the modern administrative component to manage a crisis. Other elements should be added to Islamic organisations to allow such organisations to be unique in their economic operations to form an Islamic corporate entity. This entity should not add other elements to the physical ones. Rather, it should have a direct impact on every element of the physical entity and in each of its modes because the rules and principles set by Islam are considered necessary rules and restrictive provisions. This emphasises a mixture of physical and spiritual components in a manner that could not be separated in Islamic organisations (Alqahtani \& Rosdi, 2018)

The researcher concludes from the story of Adam (PBUH) in the Qur'an that it did not clarify certain administrative means, but drew the attention of the researcher to a set of principles that could help Muslim organisations and entities manage their crises. These principles cannot be ignored because they are concerned with the spiritual dimension. If these principles are prepared in advance by Muslims, it will lead them to reach a stage of ability to help cope with the difficulties during a crisis. It would also become a protective wall before and after the crisis. By establishing these, the administrative means developed by Islam or science to manage contemporary modern crises will become easier (Shaqra, 1995). In Figure 2, the researcher illustrates the stages of applying spiritual principles: 


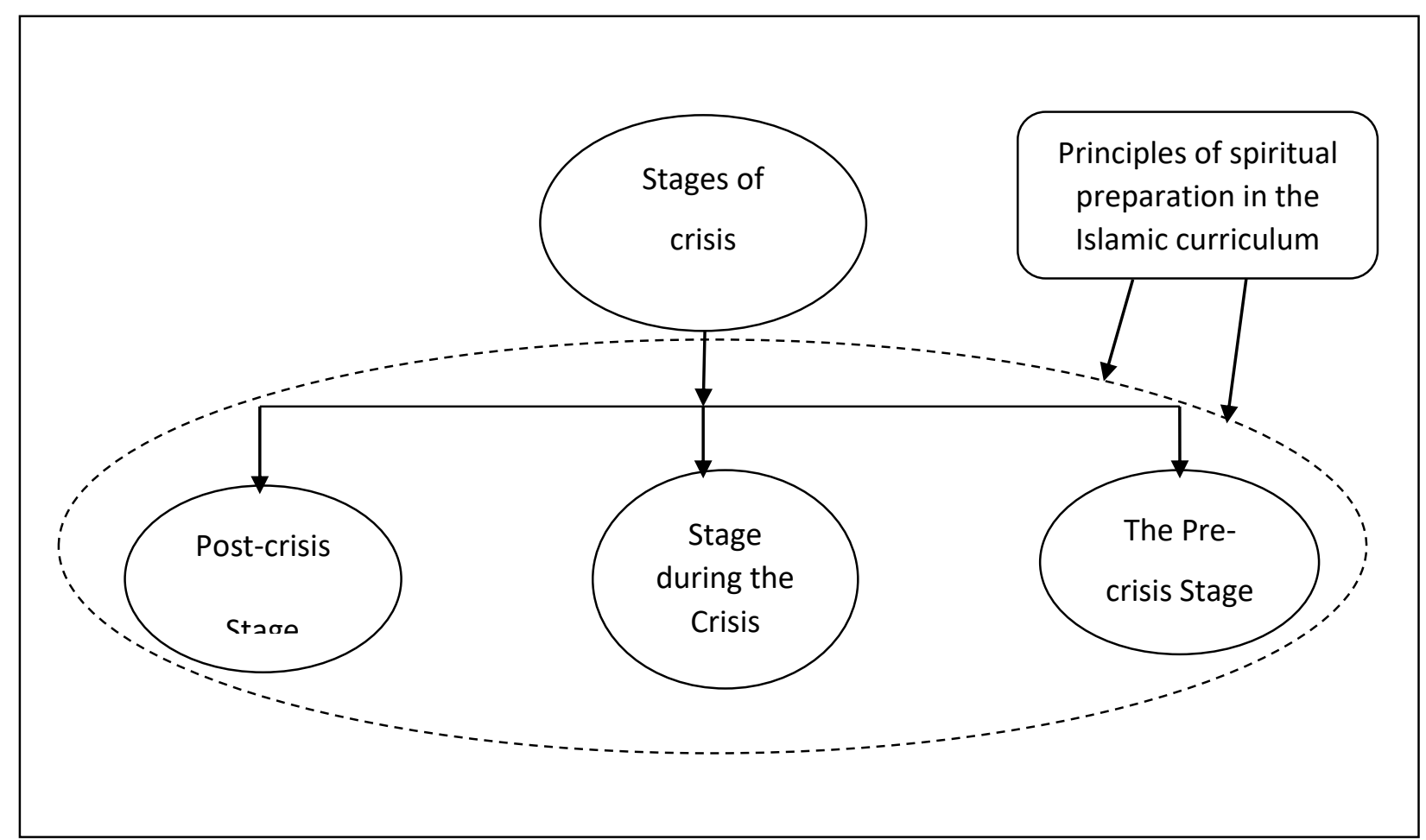

Figure 2: Concept and Stage of Applying Spiritual Principles

Based on Figure 2, the three stages of crisis management system are defined as the pre-crisis stage, during the crisis, and post-crisis stage. These principles must be applied at all stages of crisis management and must be closely linked to all stages.

The principles of spiritual formation make Islamic organisations and entities capable of coping with crises. These principles must be applied at all stages of the crisis, i.e. before the crisis, during the crisis and after the crisis, because it is concerns spiritual and ideological aspects that must be exercised by the Muslim. Based on the above, the researcher collected the principles in accordance with the previous references in Table 3: 
INTERNATIONAL JOURNAL OF ACADEMIC RESEARCH IN BUSINESS AND SOCIAL SCIENCES Vol. 9, No. 5, May, 2019, E-ISSN: 2222-6990 @ 2019 HRMARS

\begin{tabular}{|c|c|c|}
\hline No. & Learning and summarising lessons & $\begin{array}{l}\text { Principles of spiritual preparation for } \\
\text { crisis management }\end{array}$ \\
\hline 1 & $\begin{array}{l}\text { Most of the crises arise as a result of } \\
\text { disobeying the Almighty and deviating from } \\
\text { His path. }\end{array}$ & $\begin{array}{l}\text { - Obeying Allah Almighty and following His } \\
\text { orders } \\
\text { - Fearing Allah Almighty } \\
\text { - Referring to the provisions of the Qur'an } \\
\text { and Sunnah } \\
\text { - Avoiding what the Almighty has } \\
\text { prevented us }\end{array}$ \\
\hline 2 & $\begin{array}{l}\text { Satan is the greatest enemy of man whose } \\
\text { hatred for the sons of Adam will not cease. } \\
\text { This is one of the causes of crises. }\end{array}$ & $\begin{array}{l}\text { - Reliance on The Almighty } \\
\text { - Persistence on principle and not } \\
\text { abandoning faith } \\
\text { - Certainty and non-urgency }\end{array}$ \\
\hline 3 & $\begin{array}{l}\text { The people who are driven by the evil self, } \\
\text { who have obeyed and committed to its } \\
\text { desires and calls of Satan are more likely to } \\
\text { experience crises. }\end{array}$ & $\begin{array}{l}\text { - Devotion of acts for the sake of Allah } \\
\text { - Returning to Allah Almighty and sincere } \\
\text { repentance } \\
\text { - Duaa, approach and resorting to Allah } \\
\text { Almighty } \\
\text { - Adhering to ideals, values, ethics and } \\
\text { good behaviour }\end{array}$ \\
\hline 4 & $\begin{array}{l}\text { Afflictions and tribulations are tests that lead } \\
\text { to the emergence of crises. }\end{array}$ & $\begin{array}{l}\text { - Trust in Allah Almighty } \\
\text { - Certainty of the relief of Allah Almighty } \\
\text { - Taking reasons and exerting efforts } \\
\text { - Asking Allah for proper guidance and } \\
\text { seeking help from Him } \\
\text { - Patience and steadfastness on the right }\end{array}$ \\
\hline 5 & $\begin{array}{l}\text { Sanctions sent by the Almighty on the } \\
\text { infidels, disobedient and the disbelievers } \\
\text { result in crises because of their sins. }\end{array}$ & $\begin{array}{l}\text { - What has befallen you was not going to } \\
\text { miss you. } \\
\text { - Taking the warning, lessons and getting } \\
\text { advantage from previous experiences } \\
\text { - Reconsideration and accountability } \\
\text { - Punishment and reward }\end{array}$ \\
\hline
\end{tabular}

Table 3: Principles of Spiritual Preparation for Crisis Management (Al-Yaziji, 2011; Al-Otaibi and Al-Khlaiwi, 2018; Shaqra, 1995; Shaikh, 2003; Almzayen, 2009; Osama, 2002)

The researcher concludes that the Qur'anic approach in the story of Adam (PBUH) has set us a model for understanding the principles preparing us spiritually to confront and manage crises. The commitment of the sons of Adam to these principles does not mean the absence of crises, but the sons of Adam must look at the crises from two perspectives. First, to view a crisis as testing one's commitment to the principles and values of the Islamic approach. Second, to consider it as a crisis 
INTERNATIONAL JOURNAL OF ACADEMIC RESEARCH IN BUSINESS AND SOCIAL SCIENCES Vol. 9, No. 5, May, 2019, E-ISSN: 2222-6990 @ 2019 HRMARS

caused as a result of the weakness of one's faith or sin. A person has to work toward resolving the crisis, to please Allah and repent similar to the act of Adam when he repented to Allah for his disobedience.

\section{Suggestions and Conclusion}

Based on the discussion, we identified three main criteria through which we have been able to achieve the objectives of this article. First, crisis management must be derived from the stories of the Qur'an and Sunnah, to reach the spiritual, doctrinal and administrative principles in the Islamic approach. Second, the meaning of the crisis was not mentioned in the Holy Qur'an, but there are synonyms indicating the conventional meaning of crisis. Third, through the analysis, this research has highlighted some of the aspects of crisis management in the story of Adam (PBUH) which are some of the spiritual principles prepared for crisis management and must be linked to all stages of crisis management.

This clarifies that the idea of crisis management modelled in the Holy Qur'an could lead us to an effective and comprehensive concept based on a true Islamic model derived from the law of Allah. Therefore, the researcher recommends conducting complementary studies of other Qur'anic stories and applying it in the study of Islamic organisations.

\section{Corresponding Author}

Abdulla AlQahtani, Centre for Islamic Development Management Studies (ISDEV), School of Social Sciences, 11800 University Sains Malaysia, Pulau Penang, Malaysia.

E-mail: binshuhail@hotmail.com

\section{References}

Abdullah, A. and Hedayat, A. (2013), Crisis Management in Light of Doctrine: The Battle of Tabuk as a Model. Ideas 14, 79-108.

Al-Hamlawi, M. (1995) Crisis Management: Local and Global Experiences. Egypt, Ain Shams Library, Second Edition.

Al-Kailani, A. (2003) Crisis Management Heritage and Other Approach. Qatar, Center for Research and Studies, p.131-T1.

Al-Muzayen, S. (2009) an educational reading in the story of the creation of Adam, peace be upon him - Adam Start and Education. Palestine, Islamic University, Department of Fundamentals of Education.

Al-Otaibi, A., Al-Khlaiwi, L. (2018) Islamic Approach to Crisis Management. The Arab Journal for Islamic and Shari'a Studies; the Arab Foundation for Education, Science and Literature (AIESA), pp. 145- 164.

Al-Qahtani, A. \& Rosdi, M. S. (2018) The Concept of Crisis Management from an Islamic Perspective. Malaysia, Penang, University Sains Malaysia, School of Social Sciences, Centre for Islamic Development Management Studies (ISDEV), IDMAC 2018.

Al-Qur'an Mushaf al-Madinat al-Nabawiyyat. Madinah: Majma' al-Malik Fahd Li Taba'at al-Syarif. 
INTERNATIONAL JOURNAL OF ACADEMIC RESEARCH IN BUSINESS AND SOCIAL SCIENCES

Vol. 9, No. 5, May, 2019, E-ISSN: 2222-6990 @ 2019 HRMARS

Al-Qurtubi. (2006) Al Jami Li Ahkam Al Qur'an Wal Mubain Lima Tadhamanahu Min Al Sunnah W A'ay Al Furqan. study of Abdullah Al-Turki, Lebanon, Beirut, Al-Resala Foundation for Printing and Publishing.

Al-Shaikh, S. (2003) Management and Treatment of Crises in Islam. Egypt, Cairo, Publishing House of Universities, First Edition.

Al-Tabari. (2001) Tafsir Al-Tabari - Jami' al-bayān 'an Tafsir āy al-Qur'ān, the study of Dr. Abdullah Abdul Mohsen Al-Turki, Egypt, Giza, Hajar for Printing Distribution and Advertising, Center for Arab and Islamic Studies, Dar Hajar.

Al-Yaizji, S. (2011) Crisis Management inspired by the Holy Qur'an - objective study. Palestine, Gaza, Islamic University Journal in Gaza (Series of Islamic Studies) Volume XIX, No. 2, pp. 321 - 377.

Badran, G. (2011) The story of Adam between the Qur'an and the Torah - comparative study. Palestine, Al-Quds Open University Journal for Research and Studies, No. 22, pp. 291-324.

Boulagsaa, M. (2016). The Quranic approach in the management of various crises. Algeria, University of Abu Bakr Belqayd-Tlemcen, Faculty of Humanities and Social Sciences, Department of Islamic Sciences.

Katheer, I. (2000) Interpretation of the Holy Qur'an. Lebanon, Beirut, Dar Ibn Hazm Printing, Publishing \& Distributing, First Edition.

Jafar, N. \& Juareen, A. (2013) History of the World Economic Crisis. United Arab Emirates, Al Ain, University Book House, First Edition.

Khalidi, S. (2017) The Role of Public Relations in Crisis Management in the Arab World, Arab Spring Crisis as a model. Algeria, Oran, University of Oran, Faculty of Islamic Sciences and Humanities, Department of Information and Communication Sciences.

Khalil, K. (2016) Economic and Financial Crises and their Impact on Development Routes. Algeria, Algerian Journal of Economic Development, No. 5, pp. 121-131.

Ali, O. A. (2002) Crisis Management from an Islamic Perspective. Sudan, Um Durman, University of the Holy Qur'an and Islamic Sciences, College of Graduate Studies and Scientific Research.

Qarmout, N. (2009) Management in Surat Yusuf, peace be upon him - objective study. Palestine, Islamic University, College of Fundamentals of Religion, Department of Qur'an Sciences Interpretation.

Sahih-bukhari.com (2019) Quran English Arabic transliteration access on 29 January 2019 from https://www.sahih-bukhari.com/Pages/Quran/Quran_english_arabic_transliteration.php

Shaqra, M. (1995) Towards an Islamic Model of Crisis Management. Jordan, University of Jordan, College of Graduate Studies. 